Ann. Biol. anim. Bioch. Biophys., I968, 8 (г), 27-43.

\title{
A GALACTOPOEITIC EFFECT FROM OXYTOCIN ADMINISTERED BETWEEN MILKINGS IN THE COW
}

\author{
M. MORAG \\ Negev Institute for Arid Zone Research, Beersheva, (Israel)
}

SOMMAIRE

L'auteur expose les effets de l'injection d'ocytocine $(2,5$ U.I) entre les traites sur la production et la composition du lait chez la Vache. Les injections sont faites toutes $\mathrm{r}, 2$ ou 4 heures (témoins sans injections) pendant des intervalles de traite de 8 , I 2 ou 16 heures. Les expériences sont effectuées sur 24 génisses Frisonnes, selon un programme expérimental comprenant un carré latin avec un split plot. Chez $\mathrm{I} 2$ génisses le lait résiduel est extrait par injection d'ocytocine après chaque traite (groupe bleu); les I 2 autres génisses sont traites suivant la pratique agricole normale (groupe blanc). Dans le groupe bleu, on observe une réponse linéaire positive significative à l'accroissement de la fréquence des injections d'ocytocine entre les traites : l'augmentation moyenne est de $6 \mathrm{p}$. Ioo environ pour le lait, les solides et les graisses et de $20 \mathrm{p}$. Ioo environ pour le sodium ; l'effet est le plus marqué pour l'intervalle le plus long entre deux traites (I6 heures). Dans le groupe blanc, on observe une diminution de la quantité de lait proportionnelle à la fréquence des injections d'ocytocine ; la diminition de la teneur en matières grasses du lait obtenu met en évidence l'effet inhibiteur de l'ocytocine injectée entre les traites, sur l'éjection naturelle du lait. Cette inhibition masque donc tout l'effet galactopoiétique éventuel de l'ocytocine.

La production laitière du groupe bleu surpasse celle du groupe blanc d'environ $20 \mathrm{p}$. 100 .

On peut penser que l'action galactopoiétique est due à trois causes distinctes :

I. l'extraction du lait résiduel ;

2. la diminution de la pression alvéolaire particulièrement durant les longs intervalles;

3. l'augmentation de l'apport nutritionel aux tissus sécréteurs occasionnée par l'accroissement de la perméabilité de la membrane.

La signification physiologique et pratique de ces résultats est discutée.

According to the generally accepted model, lactation consists of two phases : I) milk secretion (galactopoeisis) which is under the control of a hormone complex originating in the anterior pituitary, and 2) milk removal (galactokinesis) which is controlled by oxytocin released from the posterior pituitary (FoLLEY, I956; CoWIE, I957 ; DENAMUR, I965). Oxytocin was, therefore, believed to be concerned only 
with the movement of preformed milk. Evidence has, however, accumulated which indicates that the above model may be an oversimplication and that oxytocin may also be concerned with the process of milk synthesis. SELYE (I934), showed that the suckling of ligated in rats prevented mammary involution. Similarly, BENSON and FOLLEY (I957) were able to prevent the mammary involution in weaned rats by the injection of oxytocin. In both cases the observations were based on histological examination. Galactopoietic action in response to oxytocin in laboratory species has since been reported by many authors (MEITES, I958; MEITES and NICOLI, I959; McCANn, Mack and Gale, I959; Meites and Hopkins, I96I).

There is also biochemical evidence that oxytocin has a direct effect on secretory tissue. GoOdFriend and TOPPER (I96I), and COHEN, BRENNEMAN and Topper (I962) have reported the hormone caused an increase in glucose metabolism in in vitro mammary tissue, while WHEELOCK (I966) has reported an increase in the sodium content of the milk following the injection of oxytocin in cows.

The use of oxytocin for the routine removal of residual milk in cows has been shown to cause an increase in milk yield. (KNODT and PETERSEN, I942; AdAms and Aliten, I952; Donker, Koshi and Petersen, I954; Sprain, SMith, Tyler and FosGate, I954). DENAMUR (I953) has demonstrated a similar effect in the goat, while Denamur and Mar'Tine'T (I96I) and MoRAG and Fox (Ig66) have reported the same response in the ewe. However, as more complete udder evacuation is known to have a galactopoietic effect per se (see review by MORAG, I966), one is unable to attribute the increase in milk yield to the oxytocin alone. Oxytocin did not give a similar increase in milk yield of cows when administered at times not associated with udder evacuation (GAUNyA and BuTler, I960; Milifer, LINNERUd, MARX, Carulo, DONLEER and GERRITS, I963). In these reports, the oxytocin was either exogenous, or an endogenous release elicited by udder stimulation.

This report shows the first evidence of a clear and predicable increase in the milk yield of cows in response to oxytocin administration at times not associated with udder evacuation.

\section{MATERIALS AND METHODS}

The effect of between-milking oxytocin administration on milk yield was estimates using 24 Friesan heifers. The animals, all in the third month of lactation, were ranked according to previous yield. Pairs of animals in the rank order were divided at random to provide two matched groups each of 12 animals, which were called blue and white. Each group of 12 cows, was subdivided into three blocks on the basis of previous yield and initial treatments were allocated at random within each block. The I 2 blue cows had residual milk removed at every milking with the aid of oxytocin, for to days prior to and throughout the experiment, whilst the white group was milked as in normal commercial practice. (Details of the animals are given in Table I).

The experiment was carried out using a Latin square split-plot design. The main plot treatments of the $4 \times 4$ Latin square were the different oxytocin administration frequencies defined in Table 2 , and the subplot treatments were the three milking intervals, 8, I 2 and $\mathrm{I} 6 \mathrm{~h}$, also shewn in the table. Each treatment interval was preceded by a standard $I 2 \mathrm{~h}$ discard occurring overnight. Main plot treatments were applied throughout the periods (i. e., by day and by night) so that both intervals and discard milkings provided separate estimates of the treatments. The design ignores possible within period time effects with regard to the subplot treatments. Total experimental time was $\mathrm{I} 2$ days made up of 4 periods $\times(8+\mathrm{I} 2+\mathrm{I} 6 \mathrm{~h}$ intervals $+\mathrm{I} 2+\mathrm{I} 2+\mathrm{I} 2 \mathrm{~h}$ discards $)=288 \mathrm{~h}$ $=\mathrm{I} 2$ days. 
A semi-permanent nylon jugular cannula had been inserted in all cows I I days before the experiment started. The cannula were held in place with a plaster bandage. The cows were housed in a byre, and held in the stalls by a neck chain above the plaster bandage, and remained in the stalls throughout the experiment.

TABLE I

Details of experimental animals

Détails des animaux expérimentaux

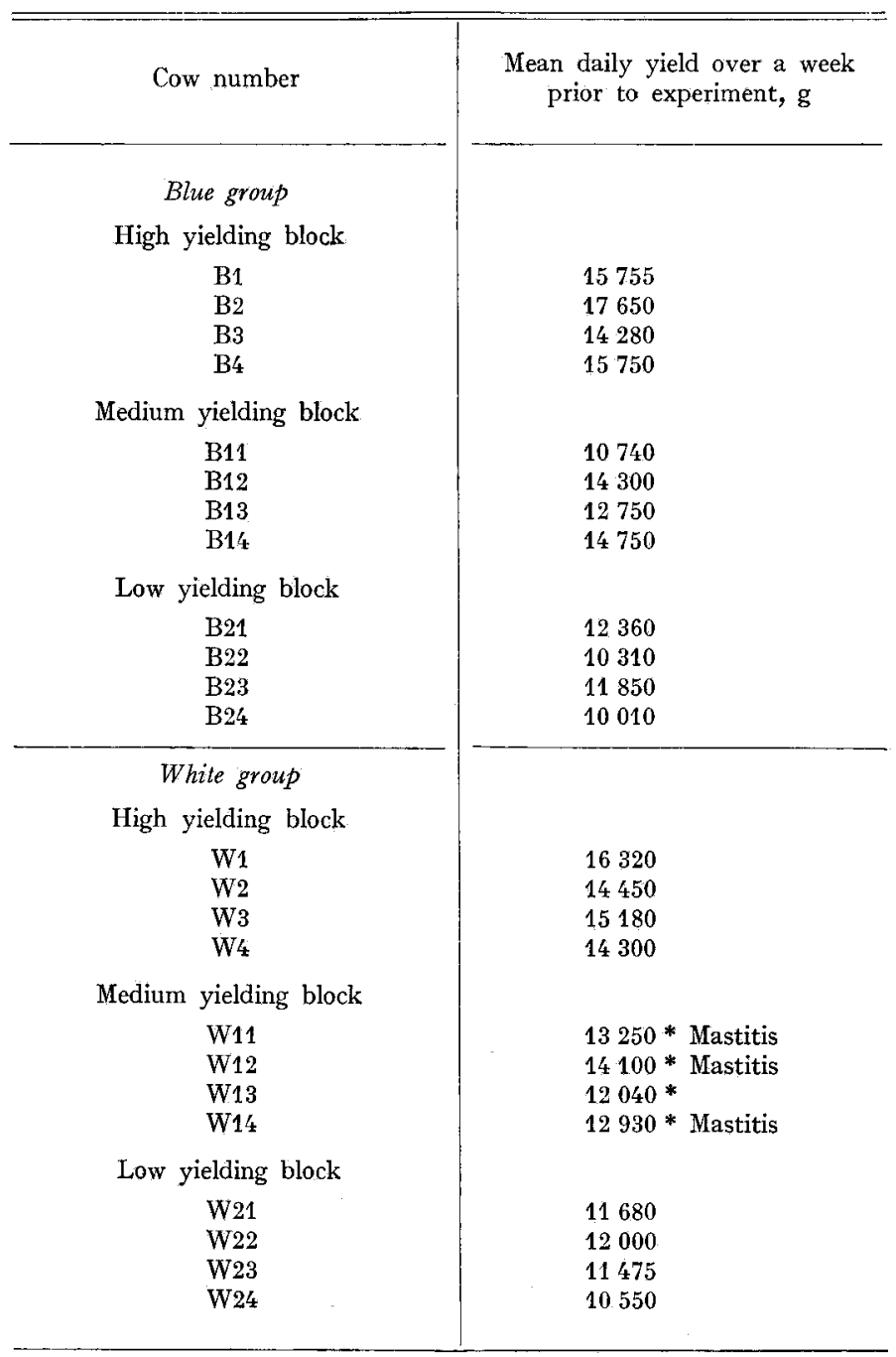

All the animals were Friesan heifers in the third month of lactation.

* Data from these cows discarded.

Milking was carried out according to a pre-determined order and the injections were timed according to treatment from the milking time. No interval or injection time varied from that planned by more than two minutes. Milking was carried out using a Gascoigne bucket plant. (Pulsation rate 
$60 / \mathrm{min}$ at a ratio of $3: \mathrm{I}$ and a vacuum of $37 \mathrm{~cm} \mathrm{Hg}$ ). No food was given immediately prior to or during milking. The bucket was placed next to the cow, the udder washed in warm disinfected water, wiped dry with a disposable towel and the teat cups immediately applied. Fore-milking was not practised. When the milk flow had ceased the cups were removed from cows in the white group. The blue group were injected with 5 i. u. oxytocin $\left(^{1}\right)$ followed by a further $2.5 \mathrm{i}$. $\mathrm{u}$. and only when the residual milk had been removed were the cups taken off. Machine stipping was carried out in both groups. All milking and injections during milking were carried out by one operator. The injections between milking; were given by thre 2 injectors working $8 \mathrm{~h}$ shifts. Both the milker and the injectors had worked previously with the herd and were known to the cows. Teats were dipped in disinfectant after milking and between-milking injections.

TABI ${ }_{4} 2$

Experimental design

Programme expérimental

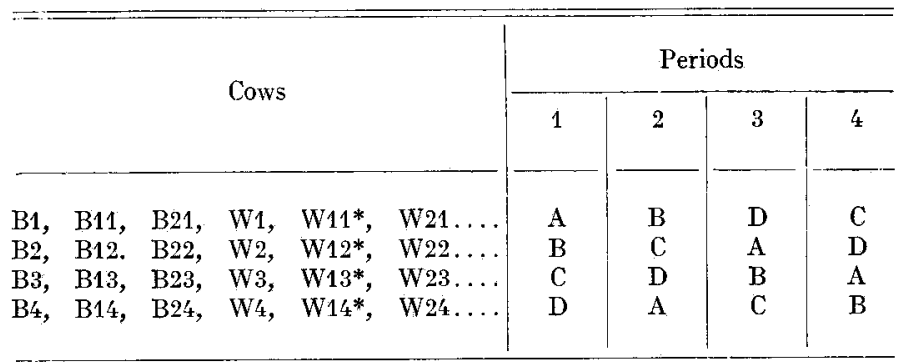

* Data from these cows discarded.

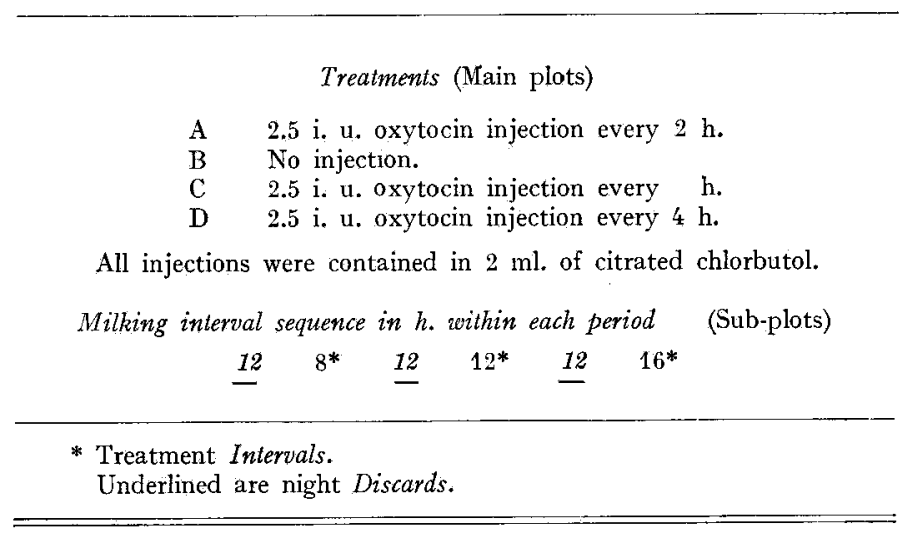

$7 \mathrm{~kg}$ of hay and $3.5 \mathrm{~kg}$ of a standard dairy nut were fed daily in two equal meals always following a milking. Water was laid on to each stall. The byre was brightly illuminated by day and night.

Milk yields were weighed to the nearest $25 \mathrm{~g}$. Total solids content was determined by the method of GOLDING (I934), fat by the method of GERBER, and sodium by the method of WHEELOCK (I966) using a Unicam S. P. goo flame spectrometer. All the animals shewed negative responses to the Californian Mastitis Test taken one day before the experiment.

The experiment was carried out at Englefield, Berkshire, from January 2 oth to February, $4^{\text {th }}$ I 966.

(1) P. O. P. Purified oxytocic principle prepared by Armours Pharmaceuticals Ltd. 


\section{RESUL'TS}

Three cows in the medium yield block of the white group developed clinical mastitis during the experiment. The data of all 4 cows in this group in this block were therefore discarded and the analysis was carried out on three yield blocks in the blue group but only on two in the white group. The hourly secretion rates of milk, water, total solids, solids-not-fat, and sodium were analyzed according to the following model :

$$
\begin{aligned}
\mathrm{Y}_{i j k l m}=\mu & +\mathrm{B}_{i}+\mathrm{C}_{i j}+\mathrm{P}_{k}+(\mathrm{BP})_{i k}+\mathrm{T}_{l}+(\mathrm{BT})_{i l}+\varepsilon_{i j k l} \\
& +\mathrm{I}_{m}+(\mathrm{IB})_{m i}+(\mathrm{IC})_{m i j}+(\mathrm{IP})_{m k}+(\mathrm{IBP})_{m i k}+(\mathrm{IT})_{m l} \\
& +(\mathrm{IBT})_{m i l}+\gamma_{i j k l m}
\end{aligned}
$$

When $\mu=$ mean secretion rate of a cow in an interval (sub-plot).

$\mathbf{B}_{i}=$ the effect due to the $i^{\text {th }}$ yield block $\left.l=\mathrm{I}, 2,3 \mathbf{(}^{\mathbf{1}}\right)$.

$\mathrm{C}_{i j}=-\quad-\quad j^{\text {th }}$ cow in the $i^{\text {h }}$ yield block $j=1,2,3,4$.

$\mathbf{P}_{k}=-\quad-\quad k^{\text {ih }}$ period $k=\mathrm{I}, 2,3,4$.

$(\mathrm{BP})_{i k}=$ - - $\quad i^{\text {th }}$ yield block in the $k^{\text {th }}$ period.

$\mathrm{T}_{l}=\quad-\quad-\quad l$ th treatment $l=\mathrm{I}, 2,3,4$.

$(\mathrm{BT})_{i l}=\quad-\quad-\quad i^{\text {th }}$ yield block in the $l$ th treatment.

$\mathrm{I}_{m}=-\quad-\quad m^{t h}$ interval $m=\mathrm{I}, 2,3$.

$(\mathrm{IB})_{m i}=\quad-\quad-\quad m^{\text {th }}$ interval in $i^{\text {th }}$ yield block.

$(\mathrm{IC})_{m i j}=-\quad-\quad m^{\text {th }}$ interval in the $j^{i t}$ cow in the $i^{\text {th }}$ yield block.

$(\mathrm{IP})_{m k}=-\quad-\quad m^{i h}$ interval in the $k^{\text {th }}$ column.

$(\mathrm{IBP})_{m i k}=-\quad-\quad m^{t h}$ interval in the $k^{t h}$ column in $\mathrm{t}^{\text {th }}$ ith yield block.

$(\mathrm{IT})_{m l}=\quad-\quad-\quad m^{\text {th }}$ interval in the $l^{l h}$ treatment.

$(\mathrm{IBT})_{m i l}=-\quad-\quad m^{t h}$ interval in the $l^{t h}$ treatment in the $i^{t h}$ yield block.

The main sub-plot means and the appropriate standard errors for the interval and discard estimates are given in Tables 3-6, figure $I$ and 2 shew the main and subplot means as three dimensional graphs. It is noted that the treatment definitions on axis $x$ appear in reverse order in the two figures.

It is noted that in the three cases that clinical mastitis was discerned it appeared on the third day of treatment $C$ (injection every hour). During the experiments milk dribble from the teats was observed on many occasions following an injection in the white group but never the blue group.

\section{DISCUSSION}

The results clearly shew that in the blue group there is a positive linear relationship between the secretion rate of milk and of milk constituents and an increasing frequency of between-milking oxytocin injection. In the white group milk

(1) In the white group $i=1,2$. 


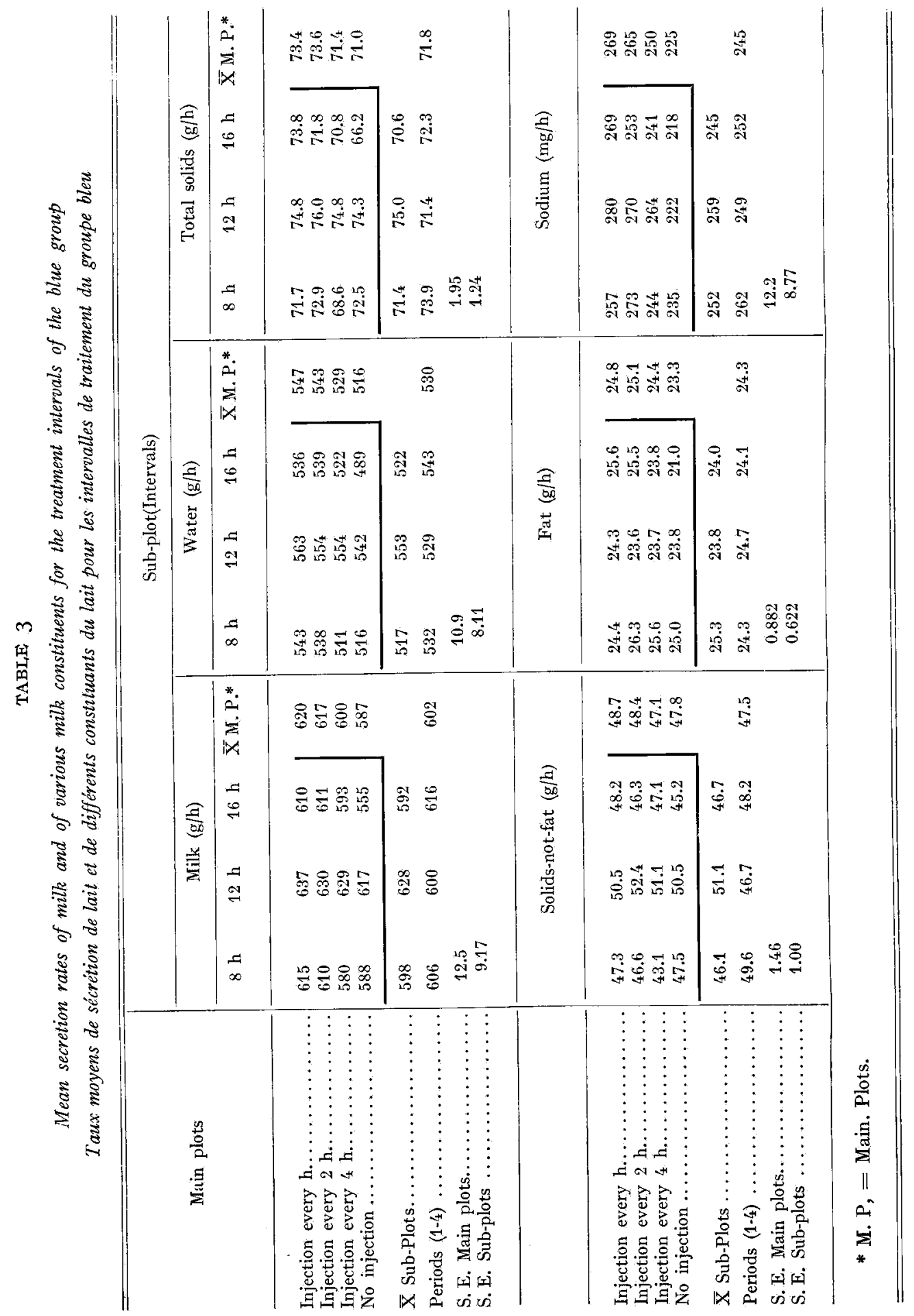


OXYTOCIN IN THE COW

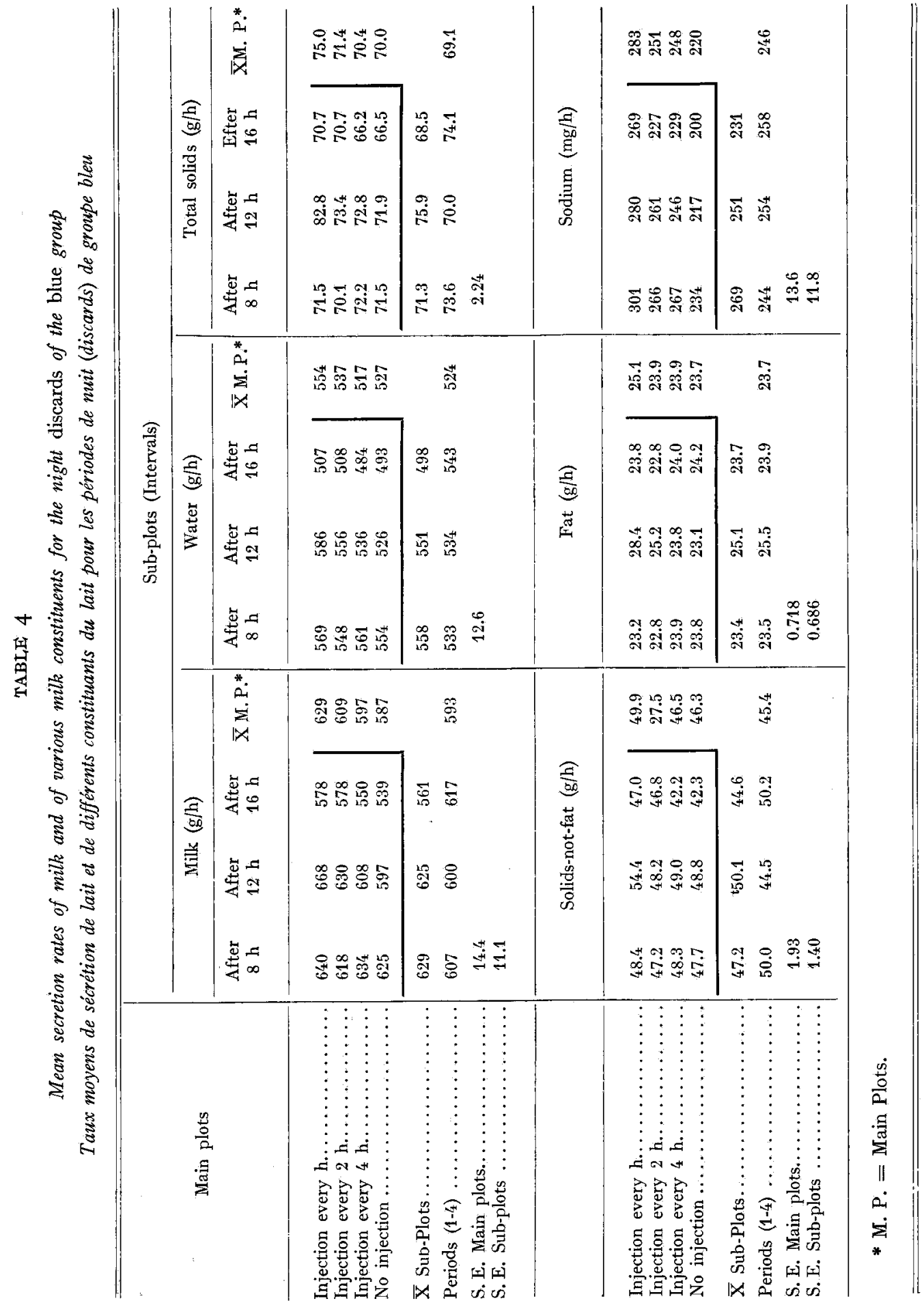

Annales de Biologie animale. - I968. 


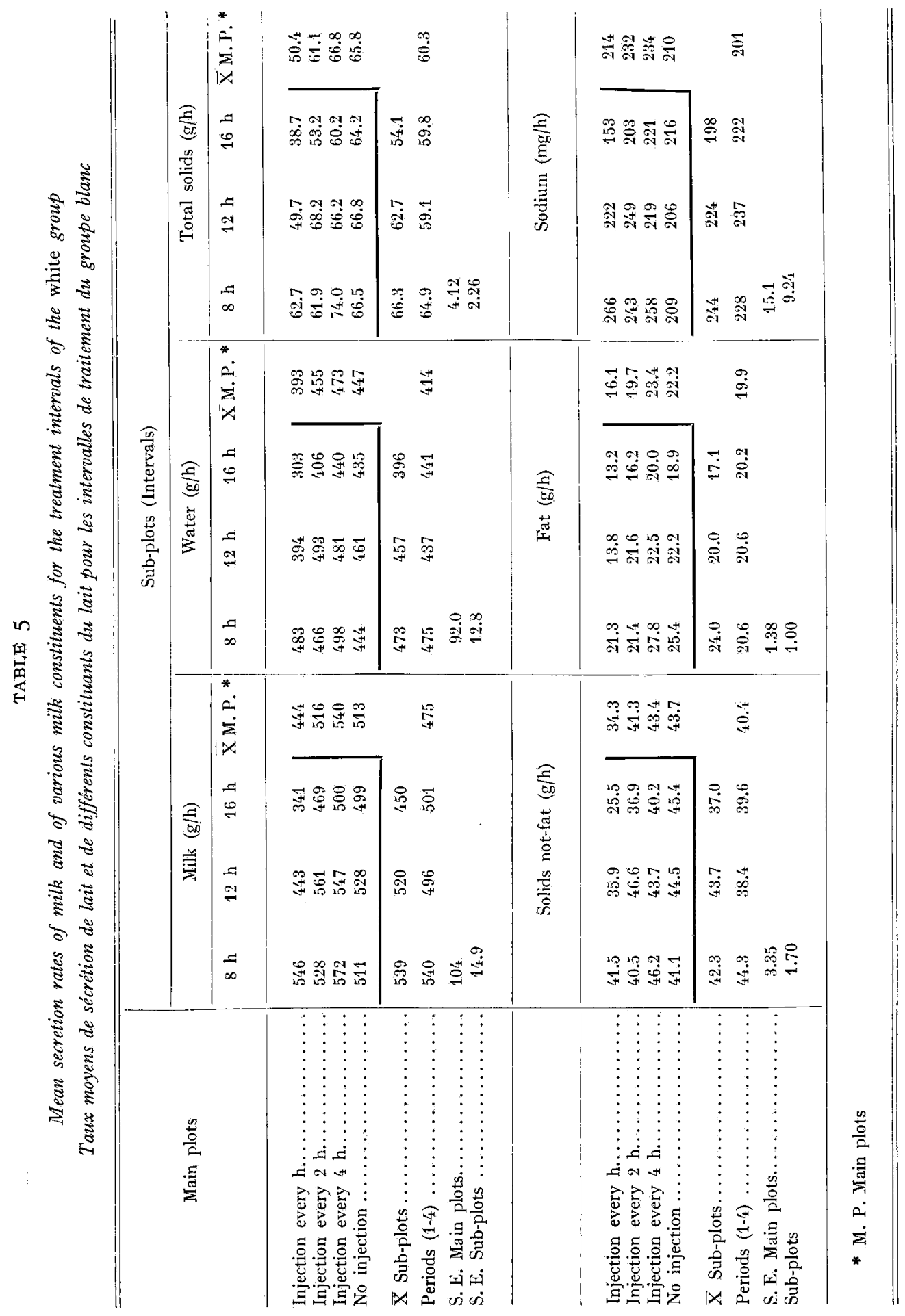




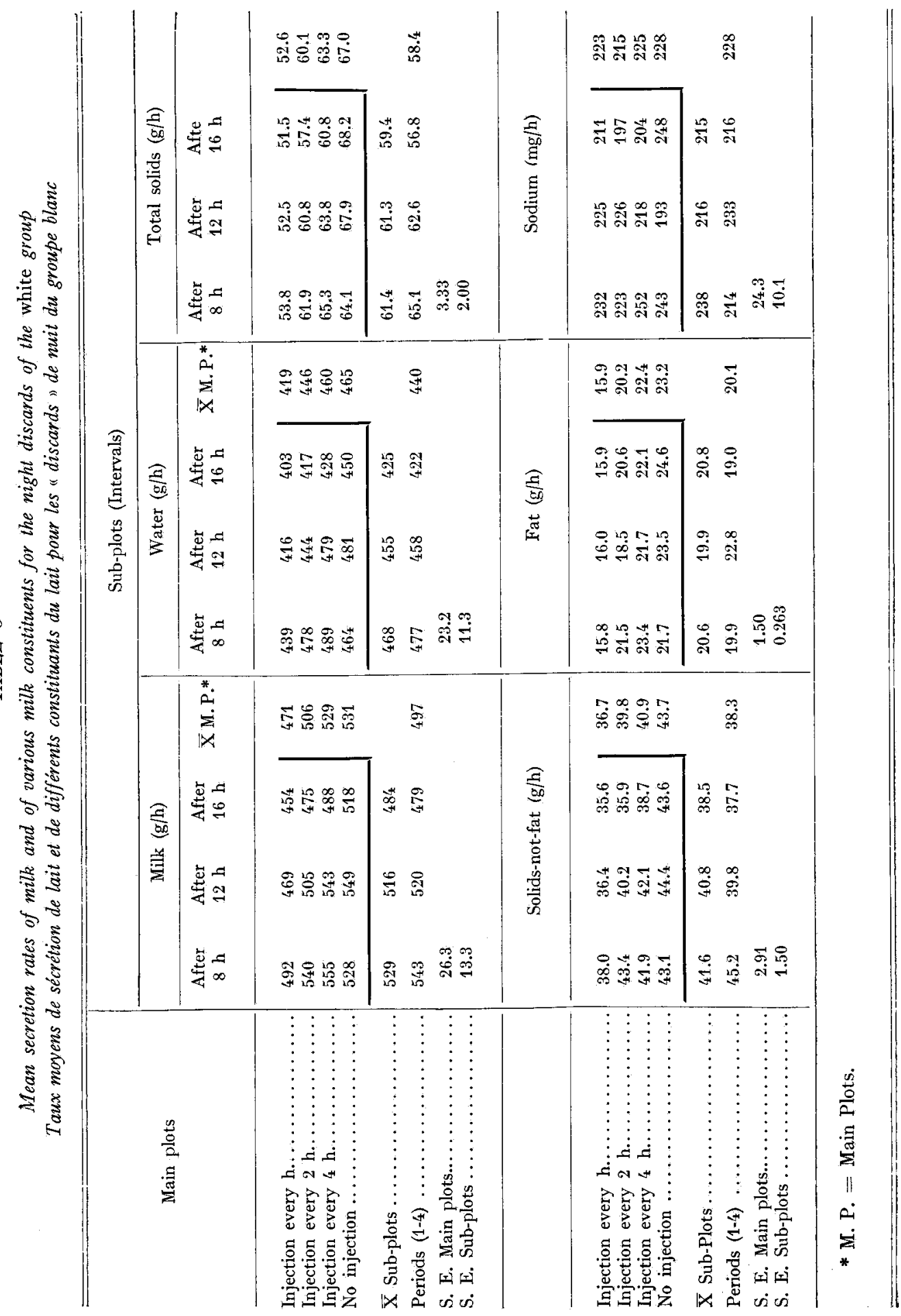


yield was apparently depressed by frequent between-milking administration of oxytocin. In both groups the described trends were similar whether estimated by day over varying interval lengths or by night during the $\mathrm{I} 2 \mathrm{~h}$ discard.

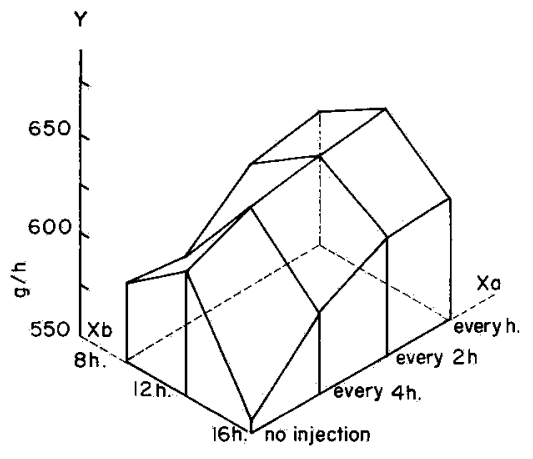

Milk $g / h$ in treatment intervals

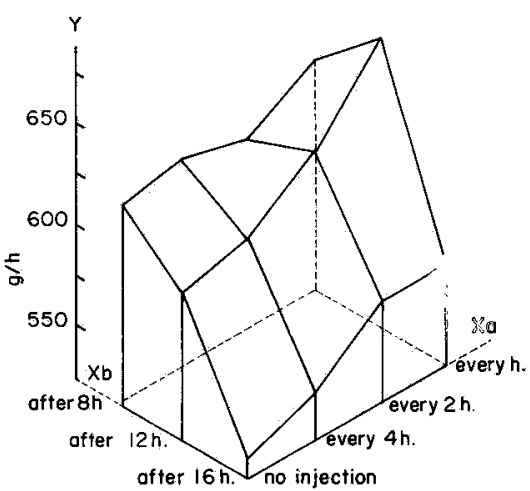

Milh oth in treotment intervals

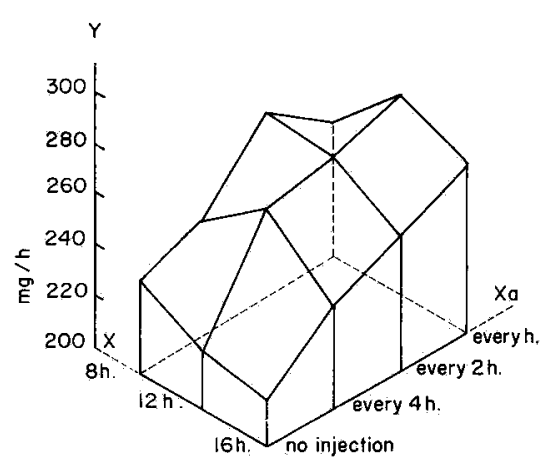

Sodium $m g / h$ in treatment intervals

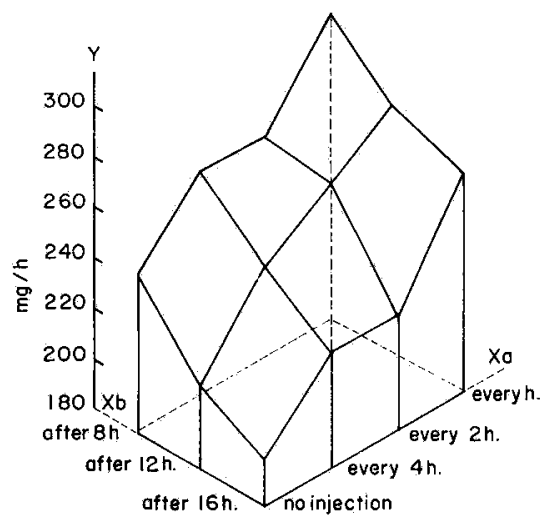

Sodium $m g / h$ in treatment intervals

FIG. I. - Secretion rates of milk and sodium in blue group.

Taux moyens de sécrétion de lait et de sodium du groupe bleu

The yield of milk obtained of any milking can be expressed algebraically (DoDD Ig66) :

$$
y=\mathrm{R}_{P}+\mathrm{S}_{T}-\mathrm{R}_{T}
$$

When $y=$ yield obtained.

$$
\begin{aligned}
& \mathrm{R}_{P}=\text { residual milk from previous interval } \\
& \mathrm{S}_{T}=\text { milk secreted during the measured interval } \\
& \mathrm{R}_{T}=\text { residual milk from measured interval }
\end{aligned}
$$

Thus in the blue group, assuming that the dose of oxytocin given at milking was effective in the removal of residual milk then $\mathrm{R}_{P}=\mathrm{R}_{T}=0$ and therefore $y=\mathrm{S}_{T}$. Now $\mathrm{S}_{T}$ is a function of the treatments (main plot) and of the interval length 
(sub-plot), and as the interaction between main and sub-plots was in all cases very small and quite without significance, the results from the blue group can only be interpreted as shewing a clear galactopoietic response to the main plot treatments.

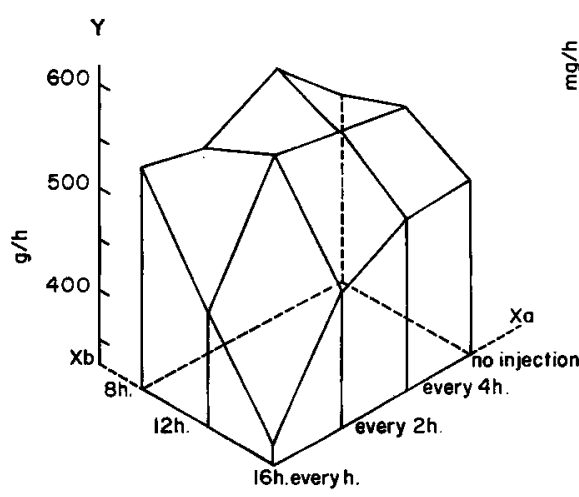

Milk $g / h$ in treatment intervals

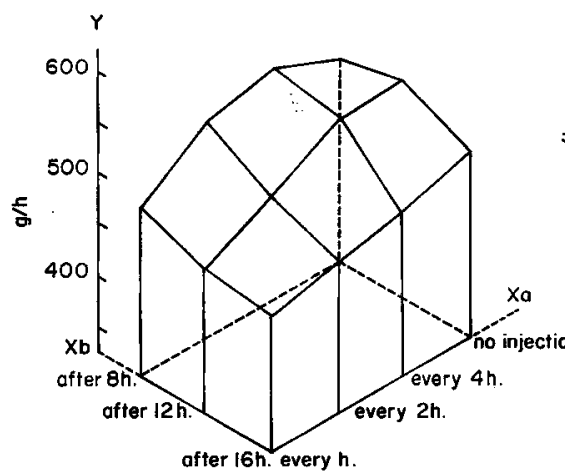

Milk $g / h$ in night discards

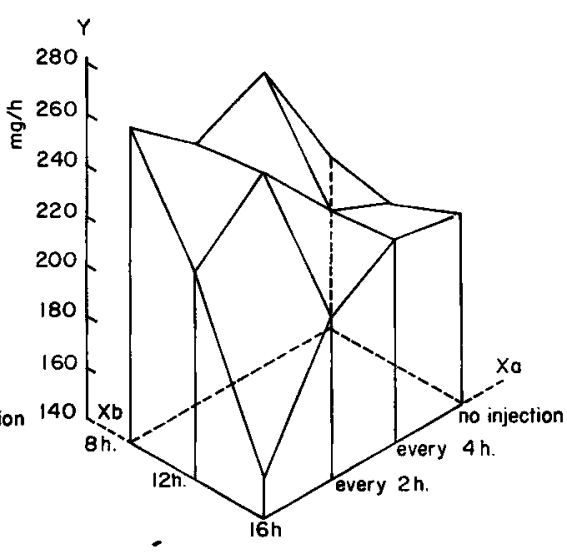

Sodium $m g / h$ in treatment intervals

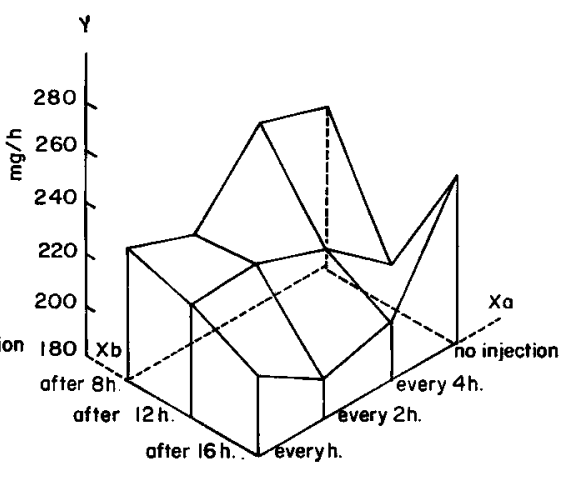

Sodium $m g / h$ in night discards

FIc. 2. - Secretion rates of milk and sodium in the white group. (treatments on axis $\mathrm{Xa}_{2}$ are in the opposite order to those in fig $\mathrm{I}$ and the scale on axis $\mathrm{Y}$ for milk is magnified)

Taux moyens de sécrétion de lail et de sodium du groupe blanc

In the white group, however, both $R_{P}$ and $R_{T}$ are unknowns and the yield obtained at any milking will thus be biased according to the relative size of these residua. In a normal milking routine the size of $\mathrm{R}_{P}$ and $\mathrm{R}_{T}$ are dependent on various factors, the main one being the interval length, but in an oxytocin routine the relative size of the residuum is greatly influenced by the supply of the exogenous hormone (Shaw, I942; Morag and Fox, I966) and the natural ejection mechanism at milking becomes partially and progressively inhibited. This effect appears at least in some general way to be dependent on the amount and/or frequency of the exogenous supply (DoDD, I966). It could thus be argued that the yield estimates of the 
white group are depressed because of an inhibited ejection at milking resulting from the between milking administration of oxytocin, and that this inhibition will be greatest on the treatment with the highest frequency of supply. Furthermore, the deleterious effect of the incomplete removal of milk on subsequent secretion is well known (see MoRAG, Ig66) and thus it can be argued that the inhibited ejection resulting in incomplete milk removal and lowered yield estimates may have a further deleterious effect on subsequent secretion. This suggestion could be advanced as the basis of a hypothesis to explain the conflicting results in the white and the blue groups. The first part of this hypothesis could have been tested if, in the blue group, the yields had been fractionated to provide separate estimates of the naturally ejected and residual milks, but this was not done. An indirect estimate of this effect can, however, be obtaines by examining the yields of milk, and particularly of fat, in the first milking following a change-over from the two extreme treatments in the white group. Table 7 sets out these values and shews a consistent picture in which

\section{TABLE 7}

Yields of milk and fat obtained after a 12 h interval immediately following the change-over from treatments $C$ (injection every $h$ ) and $B$ (no injection). Data derived from discard records of the white group

Productions de lait et de matières grasses obtenues après 12 heures d'intervalle suivant imrédiatement les changements de traitements $C$ (injection toutes les heures) et $B$ (pas d'injections). Données dérivées des résultats de la période de nuit (dicarded) du groupe blanc

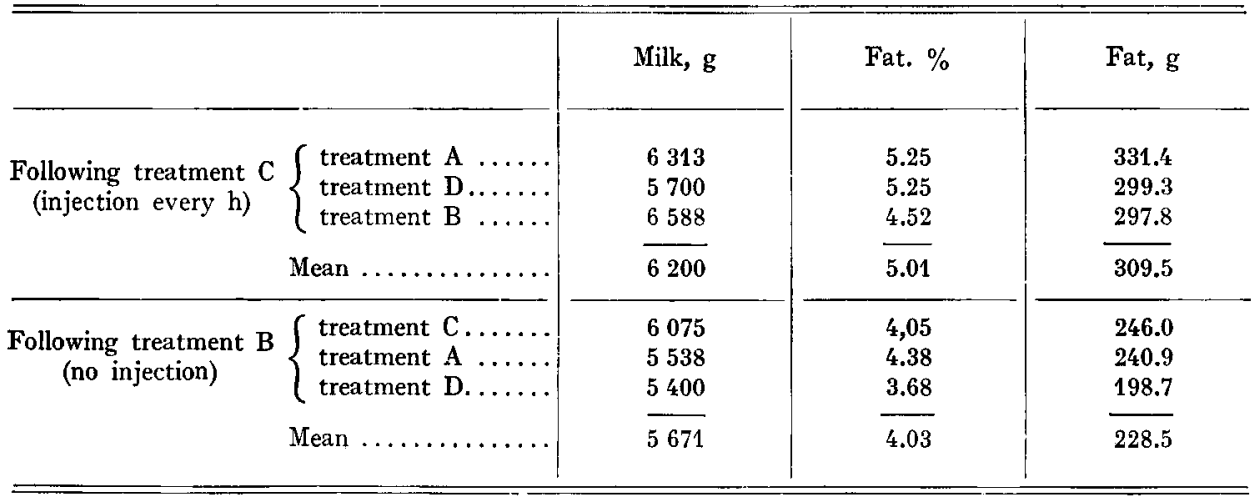

all the yields of milk and fat following treatment $\mathrm{B}$ are lower those following treatment $\mathrm{C}$. This indirect but consistent indication of an inhibition of ejection at milking on treatment $\mathrm{C}$ lends support to the hypothesis proposed above. It appears, therefore, that the yield estimates in the white group are functions of an inhibited ejection, and of a possible subsequent depression of secretion which completely masks any positive or indeed negative galactopoietic effect of exogenous oxytocin. The inability of earlier authors to demonstrate a significant response to between-milking udder stimulation or oxytocin administration (see above) can be explained in terms of this hypothesis as in all the reported studies, residual milk was not removed at milking. 
The galactopoietic effects of oxytocin in this experiment may have at least two components - the effect of between-milking administration and the effect of the removal of residual milk at milking. This latter effect can be seeen by comparing the mean performance and particularly the control treatment (B) yields of the blue and white groups). The two groups were selected at random from equal yielding pairs I5 days before the experiment started (see Table I) and as lactational peak had been established in all animals one would expect the groups to have similar yields some 28 days later. The blue group outyielded the white group by some $20 \mathrm{p}$. Ioo.

The secretion rate of milk in the blue group was significantly higher in the $\mathrm{I} 2 \mathrm{~h}$ interval than in the 8 or $\mathrm{I} 6 \mathrm{~h}$ intervals (Table 3 and fig. I). Between milking stimulation appeared to benefit the secretion rate in all intervals, but the effect appeared to be most important during the long ( $\mathrm{I} 6 \mathrm{~h}$ ) interval, since the secretion rate dropped seriously during that interval in the absence of the stimulation. This would suggest that at least part of the galactopoietic action was connected with the relief of alveolar pressure and/or the removal of newly secreted milk from the secretory tissus to the storage ducts and sinuses. One would expect such an affect to become more important as the interval becomes longer.

In the white group the secretion rate appeared to have declined with the lengthening of the interval (Table 5 and fig. 2). It is, however, impossible to speculate from these apparent secretion rates as to the relationship between interval length and secretion rate in wiew of the serious biases that operated in this group (see above).

The secretion rates in the night discards of the blue group demonstrates the deleterious effect on subsequent secretion of a lengthening of the preceding interval, and it confirms the generally accepted view that this effect becomes important only when the preceding interval exceed $\mathrm{I} 2 \mathrm{~h}$ in length. A similar decrease in secretion rate was found in the white group. This effect appears to be independent of the presence of residual milk.

The increase in milk secretion in response to the hourly injection, as compared to that in the control treatment in the blue group, was nearly $6 \mathrm{p}$. Ioo; the corresponding response in terms of sodium was some $20 \mathrm{p}$. IOO. WHEELOCK, (I96I) has noted the increase in the sodium content of the milk following an injection of oxytocin and has postulated that the increase was due to the increased permeability of the mammary epithelium. Oxytocin is known to affect the transfer of sodium across renal membranes (FRASER, I942) and across isolated frog's skin (FUHRMAN and UssING, I95I). Similarly from electrophysiological studies on the rat uterus, it would appear that the primary action of oxytocin on the smooth muscle seems to be, in fact, to lower the membrane potentiel (JUNG, I957). On the basis of the large response in sodium it could be argued that the increase in milk secretion may not only be due to a galactokinesis, but may also be associated with an increase in the supply of nutrients from the blood into the alveolar cells, which was occasioned by the action on membrane permeability. If this were so and the transport across the membrane was passive, one would expect a greater increase in the flow of the small inorganic ions than of the larger molecules of protein. On the other hand, the relief of alveolar pressure (due to the galactokinetic effect) may have accounted for all the increase in milk synthesis and only that quantity of sodium which was in excess of the general increase, may have been due to any permeability factor. Oxytocin has a common origin in the posterior pituitary and a similar chemical structure, to that 
of vasopressin. Both hormones are octapeptide amides with a 20-membered ring of five amino-acids; they differ only in two of the amino-acids. Just as vasopressin has been shewn to have uterotonic and galactokinetic as well as the typical antidiuretic action, and oxytocin has been shewn to have a weak antidiuretic action (VAN DYKE. ADAMSONS and ENGEL, I955), one can visualize biological activity of oxytocin which is similar to the main action of the related vasopressin in its concern with transport across (renal) membranes. This demonstration of a galactopoietic action of oxytocin in the cow suggest that the "milking stimulus " per se has a quantitative relationship with the level of milk secretion. The pathway could either be one by way of the galactokinetic action and/or by way of some obscure mechanism connected with the supply of milk precursors to the secretory cells. This would explain the increase in milk yield when cows are milked twice rather than thrice daily.

It is suggested that the maximum level of milk secretion may be achieved by maintaining a constant minimal level of oxytocin in the blood. This hypothesis can be tested over short periods using a venous cannula and drip technique, but any large scale, long term trial could only be carried out if the pharmacological problem associated with the production of some suitable carrier, which would allow the tissue implant of a reservoir of the hormone and its subsequent slow release into the blood, were solved. It would then be possible to achieve a constant level of oxytocin in the blood, both between and at milkings.

Oxytocin has been widely used for the elimination of biases due to residual milk in secretion rate studies ; TURNER, I955 ; ELLIOTT, I958; SchMIDT, I960 ; TUCKER, REECE and MATHER, I96I ; and LINNERUD, I964; It is pertinent in view of the present results to quote the opening paragraph in the discussion of TURNER's (loc. cit.) paper.

" These data on milk yields associated with a variety of intervals between milkings have been gathered with the aid of injections of posterior pituitary extract, the udder being emptied thoroughly by this means at the beginning and end of each experimental interval. This served to reduce errors in estimating the amount of milk secreted. There is no satisfactory evidence that oxytocin influences milk secretion other than by its effect in reducing milk stasis. Its use, therefore, should not complicate the results except in so far as the removal of residual milk at the beginning of each experimental interval increased the time taken for the udder to reach any critical degree of filling. "

In future experimental designs to the measurement of the secretion rate of milk care must be taken in the use of oxytocin. New designs will have to be employed in which oxytocin will be given only at the end of the treatment interval - giving an actual measurement only of $\mathrm{R}_{T}$. $\mathrm{R}_{P}$, (see above for nomenclature) on the other hand, will have to be estimated, since both the physical removal of $\mathrm{R}_{P}$ and the administration of the oxytocin prior to the treatment interval influence secretion. One can thus visualize the measurement of secretion rates using designs in which all treatment intervals are preceded by one or perhaps by a number of standard preceding intervals of 8 or $\mathrm{I} 2 \mathrm{~h}$ duration. The assumption would then be that the amount of residual milk at the end of the standard interval would be a constant for any given cow throughout the experiment. A treatment sequence would then look like this:

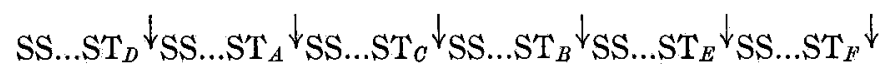


where $S$ represents a standard intervening (or preceding) interval of say 8 or I $2 \mathrm{~h}$ and $\mathrm{T}$ represents a given treatment interval in the series $\mathrm{T}_{A} \mathrm{~T}_{B} \ldots \mathrm{T}_{F}$. The arrows denote the administration of oxytocin and the removal of residual milk. The overall design could be a Latin square. A measurement of $\mathrm{R}_{P}$ could be carried out once, or even several times during the sequence, always allowing for a suitable recovery period to elapse between that measurement and the following treatment interval. The relationship between time and milk secretion given by this type of experimental design would not be biased by the galactopoietic effects of oxytocin or by the preceding interval, the lactional decline or by differences in the carry-over of residua. Such an estimate would therefore be more typical of normally milked animals than the estimates based on the oxytocin removal of residual milk.

Reçu pour publication en septembre 1967 .

\section{ACKNOWLEDGEMENTS}

This work was undertaken with grants from the Miriam Sacher Charitable Trust and the Milk Marketing Board. The author was in receipt of the Huntley and Palmer Researchship. The oxytocin was specially prepared and donated by Mr W. TICEHURST of Armours Pharmacenticals Ltd. The chemical analyses were carried out by $\mathrm{D}^{r} \mathrm{D}$. A. BALCH and Mrs B. HARDIMAN ; the statistical analyses by $\mathrm{D}^{\mathrm{r}} \mathrm{J}$. K. BROOKHOUSE and Miss J. BROMLEY who also drew the three-dimensional figures. The milking was carried out by Mr W. DAvIES. I record my appreciation to all concerned. I am also grateful to Dr F. H. DoDD, Mr S. Fox and Mr T. K. GRIFFIN for their comments at various stages of the work. I am likewise indebted to Mr M. PARAN, lately of the Israeli Embassy in London for his kind interest in this project.

\section{SUMMARY}

Experiments were carried out in which the effect on milk yield and composition of different frequencies (every 4,2 . I h or not at all) of between-milking administration of oxytocin $(2.5 \mathrm{i} . \mathrm{u})$ during three milking intervals $(8,12,16 \mathrm{~h})$ was investigated in 24 Friesan heifers. The experiment was carried out using a Latin square split plot design. In 12 heifers residual milk was removed at every milking (blue group) and the remaining animals were milked as in normal farm practice (white group). In the blue group there was a significant positive linear response to increased frequency of oxytocin administration of some $6 \mathrm{p}$. 100 in terms of milk, total solids and fat, and of some $20 \mathrm{p}$. 100 in terms of sodium. The beneficial effect was greatest in the long $(\mathrm{I} 6 \mathrm{~h})$ interval. In the white group, a negative response was observed, but from the fat content of the milk obtained it was seen that the treatments had inhibited the natural milk ejection and thus has masked any galactopoietic effect that may have been present. The blue group outyielded the white group by some Io p. I००.

The experiments indicate that oxytocin has a distinct galactopoietic role in bovines, but in order to demonstrate this effect, one must overcome, by suitable design and milking routines, the inhibition of the release of the endogenous oxytocin by the exogenous supply.

There was evidence that the galactopoiesis may be due to three distinct causes :

I. The removal of residual milk.

2. The relief of alveoler pressure particularly in the longer intervals.

3. The increase of nutrient supply to the secretory tissue occasioned by greater membrane permeability.

The physiological and practical significance of these results is discussed. 


\section{REFERENCES}

ADAms H. P., Allen N. N., 1962. Value of oxytocin for reducing fluctuations in milk and fat yield. J. Dairy Sci., 35, II 7-120.

Benson G. K., Folley S. J., I957. The effect of oxytocin on mammary gland involution in the rat. J. Endocr., 16, $189-201$.

Cohen J., Brenneman A. R., Topper Y. J., 1962. Stimulation by oxytocin and acetylcholine of glucose oxidation by lactating rat mammary-gland slices ; inhibition of the hormone effects by puromycin. Biochem. Biophys. Acta, 63, 554-556.

CowIE A. T., I957. Mammary development and lactation. In Progress in the physiology of farm animals. Ed. Hammond J. 907-96r. Butterworths Scientific Publications, London.

Denamur R., r953. Action de doses répétées d'oxcytocine sur la sécrétion du lait chez la chèvre. $C . R$. Séanc. Soc. Biol., 147, 88-91).

Denamur R., 1965. The hypothalamo-neurohypophysial system and the milk-ejection reflex. Parts I and II. Dairy Sci. Abstr., 27, 193-224, and 263-280.

Denamur R., Martinet J., 196r. Action de l'ocytocine sur la sécrétion du lait de brebis. Ann. Endocr. 22, $777-78 \mathrm{I}$.

DoDd F. H., Ig66. Personal communication.

Donker J. D., Koshi J. H., Petersen W. E., 1954. The influence of oxytocin, induced udder evacuation on milk and butterfat production in a complete lactation. J. Dairy Sci., 37, 299-305.

Ellort G. M., 1958. The effect of milk accumulation in the udder of the dairy cow upon milk secretion rate : its bearing on certain milking practices. Ph. D. Thesis, University of Reading.

FollEy. S. J., 1956. Physiology and biochemistry of lactation. Oliver and Boyd, Edinburgh and London.

FRASER A. M., 1942. Oxytocin hormone and urine secretion. J. Physiol., London, 101, 236-25.

FunRman F. A., Ussing H. H., I951. A characteristic response of the isolated frog skin potential to neurohypophysial principles and its relation to the transport of sodium and water. J. Cell Comp. Physiol., 38, IO9-I 30 .

Gaunya W. S., Butler C. E., 1960. Effect of extra udder stimulation on milk production. J. Dairy Sci., 43, 1890 .

GoLDING J., 1934. The use of the air-damped balance for the determination of total solids in milk. Analyst., 59, $468-474$.

Goodfriend T. I., TOPPER V. L., I96I. Effects of oxytocin, vasopressin, and acetylcholine on glucose metabolism in mammary tissue in vitro. J. Biol. Chem., 236, $1241-1243$.

Jung H., I957. Über den Wirkungsmechanismus des Oxytocins. (Mechanism of action of oxytocin). Arch. Gynäk., 190, 194-206.

KNODT C. B., Petersen W. E., I942. The effect of the continuous injection of pitocin upon milk and milk fat production. J. Dairy Sci., 25, 709-710.

LINNERUD A. C., 1964. The secretion rate of milk and milk components as affected by the intervals of milking. Ph.D. Thesis, University of Minnesota.

MCCANN S. M., MACK R., GALE C., 1959. The possible role of oxytocin in stimulating the release of prolactin. Endocrinology, 64, 870-889.

MeITES J., 1958. Ability of hormones to extend lactation and prevent mammary involution in parturient rats after removal of litters. J. Anim. Sci., 17, u223-т 224.

MEITES J., HoPKINS T. P. I 96r. Mechanism of action of oxytocin in retarding mammary involution : study in hypophysectomized rats. J. Endocr., 22, 207-213.

MEITES J., NiCOLL C. S., 1959. Hormonal prolongation of lactation for 75 days after litter withdrawal in post-partum rats. Endocrinology, 65, 572-579.

Miller G. E., Linnerud A. C., Marx G. D., Caruolo E. V., Donker J. D., Gerrits R. J., i963. Amount of milk obtained per day as affected by two equal milking intervals, four equal milking intervals, number of times stimulated, and methods of stimulation. J. Dairy Sci., 46, 625-626.

MORAG M., 1966. Models of milk secretion in the ewe and the cow. Ph. D. Thesis, University of Reading.

Morag M., Fox S., Ig66. Galactokinetic responses to oxytocin in the ewe. Ann. Biol. Anim. Bioch. Biophys., 6, $467-478$.

SchmidT G. H., I960. Effect of milking intervals on the rate of milk and fat secretion. J. Dairy Sci., 43, 213-219.

SEYLE H., I934. The nervous control of lactation. Amer. J. Physiol., 107, 535-538.

SHAW J. C., 1942. The effect of oxytocin on milk and milk fat secretion. J. Dairy Sci,, 25, 105I-1055.

SpRain D. G., SMith V. R., Tyler W. J., FosGate O. T., 1954. The effect on milk and fat production of injections of oxytocin at alternate 14-day periods during lactation. J. Dairy Sci., 37, 195-201. 
Tucker H. A., Reece R. P., MAther R. E., r96r. Udder capacity estimates as effected by rate of milk secretion and int ramammary pressure. J. Dairy Sci., 44, 1725-1732.

TURneR H. G., r955. Changes in the capacity of the udder of the dairy cow during the course of lactation. Aust. J. Agrig. Res, 6, 145-160.

VAN DYKe H. B., ADAMSONS K. Jr, ENGEL S, L., 1955. Aspects of the biochemistry and physiology of the neurohypophysial hormones. Receni Progr. Hormone Res. N, Y., 11, I-4I.

WHEELOCK J. V., 1966. A study of the secretion of water and water-soluble constituents of milk. Ph. D. Thesis, University of Reading. 